\title{
Swedish orka viewed through its English correspondences - ability, insufficient strength/energy or insufficient volition?
}

\author{
Mats Johansson, Lene Nordrum \\ Lund University (Sweden)
}

\begin{abstract}
This paper explores the Swedish auxiliary orka and its English correspondences as reflected in English-Swedish parallel corpora. Orka is interesting from a contrastive perspective since it lacks a straightforward equivalent in English. We show that most of the English correspondences, both in the direction Swedish original to English translation and in the direction English original to Swedish translation, indicate a semantic analysis of Swedish orka involving a combination of two meaning components 1) ability and 2) sufficient physical or mental strength/energy. We suggest an analysis inspired by Nadathur (2016) where ability is the core semantic property, but sufficiency of physical or mental energy is included in the lexical meaning of the verb as a potential obstacle to ability. In addition, our material includes correspondences reflecting a second meaning involving sufficiency of volition (von Fintel, 2006), which we assume is derived from the meaning above. We also note that orka predominantly occurs in negative polarity contexts, and speculate that the relatively recent use of the imperative form orka in informal talk, meaning something along the lines of 'I could not be bothered', might have its source in such negative connotations. In addition to offering a specified semantic description of the Swedish verb orka, our study contributes to crosslinguistic studies of expressions of sufficiency meanings and sufficiency as a meaning component in verbs (Fortuin, 2013). ${ }^{1}$
\end{abstract}

Keywords: sufficiency verbs, orka, participant-internal possibility, parallel corpora, English/Swedish

\section{Introduction}

The Swedish verb orka is interesting from a contrastive perspective since it lacks a straightforward correspondence in English. Norstedts Swedish-English Dictionary (Petti, 2000: 665), for example, provides the following idiomatic correspondences of orka:

\footnotetext{
${ }^{1}$ We are indebted to Bengt Altenberg for discovering the interesting translation patterns found for orka in the ESPC and for selflessly sharing with us his data and initial observations. We thank two anonymous reviewers of this paper for forcing us to clarify some of the ideas presented here. For all remaining mistakes, inconsistencies and plain errors, we assume full responsibility.
} 
(1) Jag (du etc.) orkar (orkade) + inf. He (you etc.) can (could) + inf.

(2) Han orkar arbeta $\mathrm{He}$ is able to work...He is capable of working.

(3) Nu orkar jag inte [hålla på] längre. I cannot go on any longer; I am too tired to go on.

(4) Om jag orkar [med det] ska jag... (har krafter nog [have sufficient strength]): if I have strength enough (the strength) for it...

(har ork [have 'energy']): if I can manage (am up to, have energy enough for) it...

As indicated in Norstedt's list, orka can function both as a main verb, especially in sense 4, and as an auxiliary, but it is considerably more frequent as an auxiliary and has been since medieval times (Lagervall, 2014: 341). Our focus in this article is on orka as an auxiliary verb. In terms of the meaning of orka, we see that Norstedt's list includes ability verbs (can, be able to) as well as expressions of the type having strength (enough), which raises the question whether orka is polysemous. In the major Swedish reference grammar, Svenska Akademiens Grammatik (Teleman et al. 1999(4): 288), however, the two meanings, ability and having strength, are described as intertwined: orka is defined as a potential auxiliary which indicates whether the subject referent has sufficient strength or stamina to bring about the state of affairs in question, and further described as "a more specified meaning than kunna (can)" [our translation].

Observations such as these raise the question of what type of semantic properties compose the meaning of orka, and how these properties are related. In other words: How can we account for Teleman et al.'s observation of a more specified meaning of kunna ('could') in semantic terms? Drawing on the general methodology proposed by Johansson (2007), we have earlier shown that the semantic account of another Swedish potential auxiliary, hinna, roughly 'having enough time to be able to do something', can be sharpened through the lens of parallel corpora (Johansson and Nordrum, 2016). In this study, we use the same general approach to explore the semantics of orka. The idea is that if we consider word-to-word translations of a lexical item as well as lexical material typically occurring in the context of the item, the semantic properties figuring in the interpretation of the item are brought to the surface, and it becomes possible to say something about how these properties are related. We consider both how orka is translated from Swedish original texts into English and cases where orka shows up in translations of English original texts.

\subsection{Orka on Modality’s Semantic Map}

The starting point for our semantic analysis is Teleman et al.'s (1999(4): 288) observation that orka is a specialization of the modal auxiliary kunna ('could'). A model suitable for illustrating such specialization and for pointing out contrastive differences with verbs in other languages is van der Auwera and Plungian's (1998) account of modality: Modality's semantic map. On Modality's map, typologically general modal meanings are illustrated as separate boxes, but the map also allows for specialized modal sub-meanings as sub-domains inside the more general meaning categories. A lexical item in one language can thus cover a large area of several general meanings (several separate boxes) whereas its most frequent correspondence in another language might cover a more limited space on the map, or perhaps only a sub-domain of one category. English may and its Dutch counterpart mogen are a case 
in point, where the latter is restricted to encoding deontic modality, whereas may has a wider range of meanings (see van der Auwera and Plungian, 1998: 89).

As illustrated in Fig. 1, the general meaning categories on Modality's semantic map are the semantic domains of possibility and necessity. The map is thus fairly restricted in terms of what is included as modality, focusing on what van der Auwera and Plungian (1998: 86) refer to as "a reasonable representation of core modality". Other accounts of modality can be more inclusive and include additional meanings, such as for example volition (see discussion in van der Auwera and Plungian, 1998: 84). The possibility/necessity distinction on Modality's map (Fig. 1) cuts across three types of modality: participant-internal modality, participantexternal modality and epistemic modality. In addition, deontic modality is included as a subdomain of participant-external modality (van der Auwera and Plungian, 1998: 82).

\begin{tabular}{|l|c|}
\hline $\begin{array}{l}\text { Participant-internal } \\
\text { possibility }\end{array}$ & Participant-internal necessity \\
\hline $\begin{array}{l}\text { Participant-external } \\
\text { possibility }\end{array}$ & Participant-external necessity \\
\hline Deontic possibility & Deontic necessity \\
\hline Epistemic possibility & Epistemic necessity \\
\hline
\end{tabular}

Figure 1. Modality’s semantic map (based on van der Auwera and Plungian, 1998: 82).

Of the meaning categories in Fig. 1, participant-internal possibility and necessity capture possible and necessary states of affairs related to a core participant's capacities, mostly the Subject, whereas participant-external modality involves possibilities or necessities mediated by some participant-external circumstance. In the case of deontic modality, which is a specialization of participant-external modality, the external circumstance is some authority or social norm. Epistemic modality, lastly, expresses the speaker's judgment of the likely truthvalue of a proposition. ${ }^{2}$ Examples (5a)-(5d) illustrate the different types of possibility and examples (6a)-(6d) the different types of necessity (van der Auwera et al., 2009: 274).

(5) a. I can swim.

(Participant-internal possibility)

b. To get to the station, you can take bus 66 .

(Participant-external possibility)

c. You can stay home - you have my permission.

(Deontic possibility)

d. He may come, or he may not - I don't know.

(Epistemic possibility)

(6) a. I have to have a cup of coffee, otherwise I can't function.

(Participant-internal necessity)

b. In order to get to the station, you have to take bus 66 .

(Participant-external necessity)

c. You must stay home now, and this is an order.

(Deontic necessity)

\footnotetext{
${ }^{2}$ An important distinction between epistemic modality and participant-internal and participant-external modality is that epistemic possibility takes scope over the entire proposition whereas the latter two types deal with "aspects internal to the state of affairs that the proposition reflects" (van der Auwera and Plungian, 1998: 82).
} 
d. He must be home now; he left for the office a long time ago. (Epistemic necessity)

Returning to orka, we note that Teleman et al.'s description places orka in the domain of participant-internal possibility. Specifically, in Teleman et al.'s (1999(4): 288) account, orka is part of a category referred to as potentiella hjälpverb ('potential auxiliaries'), which gives a latent possibility for something to happen or for someone's ability to do something. In the case of orka, the meaning proposed is that the Subject referent has enough strength or stamina to perform a certain action (Teleman et al., 1999(4): 315). In our view, the reference to 'enough strength or stamina' relates orka to an interesting category of verbs referred to as verbs of sufficiency (Flint, 1980) or sufficiency verbs (Chesterman, 2007; Johansson and Nordrum, 2016).

\subsection{Sufficiency verbs}

The Scandinavian languages and the languages spoken around the Baltic Sea feature a number of sufficiency verbs, but to our knowledge sufficiency verbs are relatively infrequent outside of this region. The largest set of sufficiency verbs are found in Finnish: In her dissertation Semantic structure in the Finnish lexicon: verbs of possibility and sufficiency, Flint (1980) lists 45 such Finnish verbs. In Flint's study, the sufficiency verbs are given the features + [possibility] and + [sufficiency] and the sufficiency feature can then be further specified to something like [time] or [strength]. Table 1 illustrates four Finnish verbs with correspondences in Swedish.

As the glosses in Table 1 indicate, the semantic category of sufficiency can be encoded in other ways than as a semantic component of verbs, and such expressions of sufficiency are more commonly discussed in the literature. Many languages include a special sufficiency marker (like English enough and Swedish nog), a construction with a purposive clause, as well as other means of encoding sufficiency. In addition, sufficiency may be contextually derived, e.g. by simple juxtaposition (see Fortuin, 2013 for a survey of ways of expressing sufficiency across 59 typologically diverse languages). It is rare, however, for sufficiency to be incorporated in the meaning of verbs. As noted above, Finnish has a rich inventory of sufficiency verbs, English has dare and the more general suffice, whereas the Scandinavian languages fall somewhere in between with a handful of sufficiency verbs which specify the type of sufficiency (e.g. sufficiency with respect to a notion of strength/energy for orka).

Table 1. Four sufficiency verbs in Finnish and Swedish with English glosses

\begin{tabular}{llll}
\hline Sufficiency category & Finnish Verb & Swedish verb & English gloss \\
\hline Time & ehtii & hinna & To have enough time \\
Energy & jakssaa & orka & To have enough strength/energy \\
Space & passaa & passa & 'Fit' [to be big/small enough] \\
Boldness & kehtaa & våga & 'Dare' [to be bold enough] \\
\hline
\end{tabular}

An interesting question is thus whether 'the sufficiency component' is the only semantic property of a sufficiency verb, and if it is not, whether it is the most salient property. In a previous study of the Swedish sufficiency verb hinna ("have enough time to be able to [do sth]') ( Johansson and Nordrum, 2016), we argue that the English correspondences of hinna reflect a meaning where time sufficiency is the most salient, at-issue, meaning of the verb, but that the verb also reflects an ability meaning, which is backgrounded. In the terminology of van der Auwera and Plungian's Modality's map (1998), we view time sufficiency as 
participant-external possibility and ability as participant-internal possibility, and hinna thus covers two contiguous areas on the map.

For orka, in contrast, the sufficiency component cannot really be disentangled from participant-internal possibility since both 'having enough energy' and 'being able to' reflect participant-internal modality. Rather, as suggested by Teleman et al., (1999(4): 315), sufficiency seems to be a sort of 'specialization' of participant-internal modality. In this study, we use translation data in parallel corpora to shed light on how this specialization can be described, and explore whether there are other meaning components of orka that are not captured by the description in the Swedish reference grammar or by dictionary entries.

\section{Method and material}

Following the general methodology 'seeing language through multilingual corpora' (Johansson, 2007), this paper explores the meaning of orka as mirrored in parallel translation corpora. The material was drawn from The English-Swedish Parallel Corpora (ESPC), comprising approximately 650,000 words (Altenberg and Aijmer, 2000), ${ }^{3}$ and from the Swedish-English components of The European Parliament Proceedings Parallel Corpus (Europarl) and the Amsterdam Slavic Parallel Aligned Corpus (ASPAC). The two components comprise 33,406,922 words and 1,516,943 words, respectively. All corpora are available from the search interface KORP, ${ }^{4}$ managed by the Swedish Language Bank ('Språkbanken'), University of Gothenburg (Borin et al., 2012). The ESPC includes written texts, non-fiction and fiction, mainly published between 1980 and 2000, while the material from Europarl contains non-fiction texts in the form of scripted speeches from the late $20^{\text {th }}$ century to the present day. The ASPAC material, lastly, contains fiction texts from the beginning of the $20^{\text {th }}$ century to the present day. Both the direction Swedish original to English translation $(\mathrm{SO} \rightarrow \mathrm{ET})$ and English original to Swedish translation (ST $\leftarrow$ EO) were investigated. Since the Europarl and ASPAC corpora do not allow searches that distinguish between the original texts and the translated text respectively, the data from these corpora were sorted manually into original and translations based on the metadata.

Data collection and analysis involved a sequence of steps. First, instances of orka were retrieved and manually cleaned so that only instances of orka as an auxiliary verb remained. Next, English correspondences were extracted from the parallel corpora's sentence alignment interface, transferred to a database, and supplemented with information about the type of English correspondence and the syntactic and semantic context in both the original and the source text. The examples were then sorted according to translation correspondence and further analysed for patterns.

Some limitations should be noted. First, it is clear that the material does not provide a balanced empirical foundation for a comprehensive study of the meaning of orka across registers and dialects; for one, informal talk is not included in the material and some of the examples are retrieved from written texts from the beginning of the $20^{\text {th }}$ century. It follows that orka may include meanings and meaning components that are not reflected in our material, and our study is therefore mainly exploratory. Further, the number of examples is limited, which means that frequency can only inform arguments, not validate them. Despite these shortcomings, however, our data has the unique advantage that meaning can be explored through the lens of authentic interpretations of orka. That is, neither the source texts

\footnotetext{
3 A description of the corpus is also available at http://www.sprak.gu.se/english/research/researchactivities/corpus-linguistics/corpora-at-the-dll/espc/.

${ }^{4}$ The KORP interface is available at https://spraakbanken.gu.se/korp.
} 
nor the translations were produced with a theoretical agenda (see Aijmer, 2004), which ensures authenticity of data.

\section{Exploring the English correspondences and contexts of orka}

Table 2 gives the English correspondences of the lemma orka in our material. In this section, we use these correspondences to shed light on the semantic profile of orka, but it should be noted that the correspondences are not necessarily addressed in the order in which they are listed in Table 2. The section is organized so that we first deal with translations that seem to focus on ability meaning, such as can in Table 2 (Section 3.1), and then on such examples that seem to focus on sufficiency of energy or strength, such as have the energy strength to in Table 2 (Section 3.2). Next, we move to a more general discussion of sufficiency (Section 3.3), before addressing the observation that the overwhelming majority of our orka examples occur in non-assertive contexts (Section 3.4). We end the section with some observations of orka in translations with be bothered/fed up with (Table 2), which we argue focus on volition rather than ability (Section 3.5).

Table 2. The English correspondences of $o r k a$ in the parallel corpora*

\begin{tabular}{lllll}
\hline English correspondence & \multicolumn{3}{c}{ SO $\rightarrow$ ET } & \multicolumn{3}{c}{ ST EO } \\
& $\mathrm{N} 104$ & $\%$ & $\mathrm{~N} 29$ & $\%$ \\
\hline Can & 29 & 27.9 & 10 & 33.5 \\
Be (un)able to & 12 & 11.5 & 4 & 14 \\
(Can) Manage & 17 & 16.3 & 2 & 7 \\
Can bear/cope/stand/face/bring & 9 & 8.7 & 1 & 3.5 \\
HAVE (enough/the) strength/energy to+inf & 8 & 7.7 & 1 & 3.5 \\
Be bothered/be fed up/feel like & 7 & 6.7 & 1 & 3.5 \\
too Adj to+inf & 5 & 4.8 & 3 & 10.5 \\
Can find the energy/have energy, get strength & 3 & 2.9 & - & - \\
Zero & 5 & 4.8 & 3 & 10.5 \\
Other & 9 & 8.7 & 4 & 14 \\
\hline SUM & 104 & 100 & 29 & 100 \\
\hline
\end{tabular}

*The term 'correspondence' refers to both sources and translations of orka (Johansson, 2007: 23). Table 2 gives both congruent correspondences and divergent correspondences of orka. Congruent correspondences are those where the source syntax is kept intact (Johansson, 2007: 23-26) and orka corresponds to an auxiliary or semiauxiliary, while divergent correspondences are those with a different syntactic structure, as in the correspondence too Adj to + inf. It should be noted, however, that none of the correspondences listed in Table 1 involves major syntactic changes.

\subsection{Ability}

Roughly half of the translations and the sources of orka in Table 2 correspond to a modal auxiliary reflecting 'ability' meaning, which indicates that ability is a prominent meaning component in orka. Under ability, we include correspondences with can, be (un)able to, and (can) manage. However, a closer look at the correspondences with ability suggests that the meaning component sufficiency of mental/physical strength is usually reflected as well, or is supplied by the context.

In the vast majority of the ability correspondences, an aspectual/durative adverbial indicating that the ability is subject to exhaustion is present in the context, thus adding a sufficiency element, a pattern that is also noted in Norstedt's dictionary (see entry 3 in (1), p. 
156). Example (7) illustrates the context with an aspectual/durative adverbial in the direction $\mathrm{SO} \rightarrow \mathrm{ET}$, and example (8) in the direction ST $\leftarrow$ EO. ${ }^{5}$

(7) Hur länge skall jag orka vara dessa barns samlande punkt? (GT1)

How long will he be able to be the center of these children's lives? (GT1T)

(8) He shut his eyes and wondered if he could hold on any longer. (JRT1)

Han slöt ögonen och undrade om han skulle orka hålla sig fast längre. (JRT1T)

We note that the aspectual/durative adverbial is always present in both the English original and in the Swedish translation in our material, but can be added in the English translations, as in (9).

(9) Han orkade inte prata utan gick och lade sig. (SL1)

He could hardly talk any more, so he went to bed. (SL1T)

We would argue that the addition of an aspectual adverbial in (9) is a way for the translator to capture that orka encodes sufficiency as well as ability meaning. Even if it is not possible to claim that the adverbial any more mirrors a sufficiency component, it does reflect the possibility that the Subject's ability to talk is not permanent, but subject to exhaustion, which can then be related to sufficiency. In (9), the sufficiency relation comes in via the coordinated clause, so he went to bed, which gives the likely reason why the Subject cannot talk any longer: he is probably too tired, implying that he lacked sufficient strength to talk due to tiredness. Without any more, in contrast, the English translation in (9) risks being interpreted as permanent inability since could on its own does not encode sufficiency meaning.

The presence of sufficiency meaning is even clearer in another context noted among the ability correspondences. The context in question involves an adjective modified by so...that indicating that a state of exhaustion has been reached which interferes with the Subject's ability. The context only shows up in the direction $\mathrm{SO} \rightarrow \mathrm{ET}$, and is illustrated in (10) and (11).

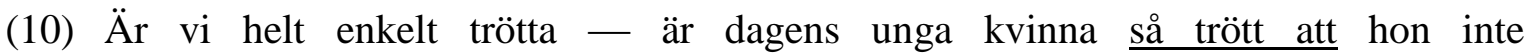
längre orkar säga det hon känner att hon måste säga — eller har vi ingenting mer att säga varandra på det sedvanliga debattspråket? (MS1)

Is the woman of today so tired that she is unable to say what she ought to be saying in accord with her feelings? Or have we no more to say to each other in the current jargon? (MS1T)

(11) Han var så dåsig, att han knappt orkade göra sig mödan att sänka blickarna. (SL1) He was so drowsy that he could barely rouse himself enough to lower his glance. (SL1T)

It can also be noted that the Swedish original in (10) includes an adverbial, längre, which can be compared to any more in the English translation above (9).

\footnotetext{
${ }^{5}$ All the examples in the text mark orka and its source translation in italics, whereas other structures relevant in the discussion are underlined. In each case, the initials of the author of the text are provided in parentheses, where $\mathrm{T}$ indicates that the text is a translation. The source texts can be found in the search interfaces for the corpora listed under references.
} 
A variant of the so...that context is the non-congruent correspondence too Adj to +inf, where it could be maintained that the expression involves a covert ability modal encoded as an infinitive (see Meier, 2003; Hacquard, 2005). This correspondence figures both as a source and as a translation of orka, and includes adjectives such as tired, exhausted, feeble, ill, sick and weary. Examples (12) and (13) are illustrations.

(12) Nej, uppriktigt sagt inte. Men jag orkar inte leta efter den andra texten nu. (MG1) No, to be honest, it wasn't. But I 'm too tired to look for the other passage now. (MG1T)

(13) There they dropped off one by one into uncomfortable sleep full of horrible dreams, as evening wore to black night; and there we must leave them for the present, too sick and weary to set guards or take turns watching. (JRT1)

Så föll de en efter en i en orolig sömn full av mardrömmar, medan kvällen övergick i svart natt, och där måste vi lämna dem för ett tag, alltför trötta och dåliga att orka sätta ut vakter eller turas om att speja. (JRT1T)

We suggest that both the ability correspondence (e.g., be able to) combined with an adjective modified with so...that and the too Adj to+inf correspondences provide a sufficiency condition related to the potential exhaustion of the Subject's ability. This sufficiency condition is specified by an adjective associated with sufficient/necessary amount of energy/strength (such as tired or ill) and thus related to a point on a scale that marks when the Subject has the necessary amount of some physical or mental entity to carry out a certain act.

In one example in the material, (14), the idea of a point on a scale is made specific by the sufficiency marker enough.

(14) Jag var tillräckligt stark för att orka knuffa ned en fyllgubbe i vattnet. (SL1) I was strong enough to shove an old drunk into the water. (SL1T)

In (14), then, we would argue that ability is realized as covert modality in the to-infinitive and the sufficiency condition is realized in general sufficiency terms: with the adverb enough. (see e.g. Fortuin, 2013). The Swedish original also has tillräckligt 'enough', which, in a sense, 'doubles' the sufficiency component of orka.

\subsection{Sufficiency}

Table 2 also includes a HAVE (enough/the) strength/energy to + inf correspondence, illustrated in (15) and (16).

(15) Han orkade inte bruka årorna, men i stället satte han sig att vagga och gunga i eka. (SL1)

He had not strength enough to use the oars, but instead, he seated himself to swing and rock in the scow. (SL1T)

(16) Och framför allt orkade han inte ta itu med den biten samtidigt som han skulle ge sig på Wennerström. (SL1)

Above all, he did not have the energy to deal with that problem at the same time as he was tackling Wennerström. (SL1T) 
We initially observe that there is a potential pattern in the material that strength is used for physical strength and energy for mental strength, but this pattern is not clear. For one, it is not always straightforward whether the reference to strength/energy is to physical or mental strength, as in (17), where both possibilities seem plausible.

(17) Det har snart gått två veckor sedan jag skrev sist. Jag har inte orkat. (LH1) It has been almost a fortnight since I've written anything. I have n't had the strength. (LH1T)

Another observation for the correspondences with strength/energy is that the ability component of orka seems lost in translation. However, we would argue that it is not. In line with our observation about the to-infinitives in the too Adj to +inf correspondences (section 3.1 ), we note that the correspondence HAVE (enough/the) strength/energy to + inf arguably contains covert ability modality encoded in the infinitive. On this view, the correspondence profiles both a sufficiency condition, have enough strength/energy, as well as ability in the infinitive, roughly: have enough strength/energy to be able to do something.

Interestingly, our material includes only one example, (18), where orka is introduced as the correspondence of an expression with strength or energy in an English original text.

(18) "Don't mind the house, child. I know it 's a mess but I ai n't got the strength I once had to keep it tidy". (GN1)

"Bekymra dig inte för oredan, lilla vän. Jag vet att det är rörigt, men jag orkar inte hålla det så fint som förr”. (GN1T)

The obvious reason why HAVE (enough/the) strength/energy to + inf is not a common source of orka is that the parallel corpora include very few examples of this construction, nine in total. We note, though, that six of these nine instances are translated with a corresponding phrase in Swedish, as exemplified in (19) and (20).

(19) Would she have the energy to seek one out? (FW1)

Skulle hon ha energi nog att leta upp en? (FW1T)

(20) It seemed that bingo afternoons left her so exhausted both physically and emotionally that she never had enough energy left to cook an evening meal. (RD1) Det verkade som om hennes bingo eftermiddagar gjorde henne så utsjasad både fysiskt och psykiskt att hon aldrig hade tillräckligt med energi kvar för att laga middag åt dem. (RD1T)

This strategy may reflect a tendency for translators to pick a translation that represents the closest formal correspondence to the source item, in line with some principle of equivalence, a principle that has been debated from numerous angles in translation theory over the years (Nida and Taber, 1982; Baker, 1992), but this explanation remains speculative.

What can be concluded, however, is that similarly to the ability translations commented on in section 3.1, the pattern with an aspectual/durative adverbial is also prominent for the HAVE (enough/the) strength/energy to + inf translations, as in (21).

(21) "Inget barn behöver svälta ihjäl, så länge Karlsson orkar släpa fram korv och potatis". (AL2) 
"No child need starve, as long as Karlson has the strength to deliver the sausage and mash". (AL2T)

At this point, then, we note that a precise semantic definition of orka seems to include two semantic components: ability and sufficiency of mental/physical strength. The relation between the two components is difficult to tease out, but it is clear that the ability component is always overtly reflected in some form in the correspondence itself, whereas the sufficiency component can come in via the context. For the translations where orka corresponds to an ability modal such as could or be able to, sufficiency comes in via the expressions so Adj that in the context, or a sufficiency condition is suggested by an adverbial/aspectual adverbial. In the translations with energy/strength, ability is expressed by means of covert modality in the form of a to-infinitive and sufficiency is reflected in the HAVE (enough/the) strength/energy translation. For this correspondence too, an aspectual/durative adverbial is generally present in the context.

\subsection{Sufficiency as an obstacle to ability}

A possible way to view the relationship between the two meaning components, ability and sufficiency, is that the sufficiency component highlights that there is a potential obstacle to the ability component, specified to a point where the Subject's physical or mental strength is insufficient or running out. This type of analysis has been forwarded by Nadathur (2016) to explain the semantics of Finnish jaksaa, a sufficiency verb corresponding to Swedish orka. Nadathur's analysis is part of a discussion of implicative verbs, a discussion that is beyond the scope of our article, but some of her observations are relevant to our interpretation of orka. Inspired by a proposal by Baglini \& Francez (2016), Nadathur proposes that jaksaa involves sufficient strength as a causally necessary, but contextually insufficient, factor for the realization of jaksaa's complement verb. On this analysis, orka would reflect a Subject's ability to do something, but also highlight that this ability is potentially obstructed by the amount of physical or mental strength available to the specific individual in the specific situation. The proposal that the factor is contextually insufficient explains that even if a Subject has sufficient strength to be able to do something, it does not follow that he or she actually does it - there may be other factors involved in this decision. Interestingly, Nadathur (2016: 1010) points out that jaksaa is similar to manage in assuming a potential obstacle, but that manage does not specify what the obstacle is.

The idea of sufficiency of strength as an obstacle fits with our data. For example, the translations (can) manage (Table 2) can be viewed as a generalization of the obstacle sufficient strength. In such instances, specification to sufficiency of strength is brought in by the context. In (22), the reference to the Subject being "ill and miserable" seem to achieve such specification.

(22) "Det ska bli ganska intressant att se, om jag orkar mer än halvvägs, sjuk och eländig som jag är". (AL2)

"It will be quite interesting to see if I manage to get further than halfway, while I am all ill and miserable like this". (AL2)

Also, somewhat tentatively, we interpret another category of verbs found in the translations of orka as mirroring a general obstacle. The verbs in question are bear, cope and face. As shown in Table 2, the material includes nine translations where these verbs combine with the ability modal can, all in non-assertive contexts. Example (23) is an illustration. 
(23) Han påminde Lisbeth om att klockan var mitt i natten och påstod att han inte orkade tänka på saken. (SL1)

It was the middle of the night. He could not face thinking about the whole thing now. (SL1T)

In (23), we would argue that ability meaning is reflected in can, and that face in the English translation profiles a potential obstacle, but the context is necessary to specify the obstacle to sufficient strength. In (23), such specification is suggested by the reference to time, the middle of the night, which suggests that the Subject, he, might need sleep and thus does not have sufficient mental or physical strength to be able to think properly.

We also note that in most of the examples with orka, the obstacle is not overcome, i.e. orka appears in a non-assertive context. On an intuitive note, the non-assertive contexts can be expected from the type of obstacle profiled in orka: If you do not have sufficient strength to do something, you may want to make this obstacle salient. If, on the other hand, you have sufficient strength to do something, it might be more likely that you simply say that you did it. On a more formal note, however, the negative contexts raise the question of whether orka can be viewed as a so-called Negative Polarity Item (NPI), i.e. a lexical item that can only appear in contexts with negative grammatical polarity.

\subsection{The negative association of orka}

In the vast majority of the occurrences of orka, both in the SO and the ST texts, orka appears in non-assertive contexts where it has been shown that negative polarity items (NPIs) would be triggered (see Lawler, 2005 for an extensive list of NPIs and NPI triggers in English). This is also noted by Teleman et al. (1999(4): 311). Below, we refer to these contexts as NPI triggers. By far the most common NPI trigger in the material is sentence negation, as in (24).

(24) Ronja förstod att det var synd om Skalle-Per som var så gammal, men hon förstod inte varför knektar och trindskallar skulle komma och bråka vid Vargklämman. Förresten var hon sömnig och orkade inte bry sej om det heller. (AL1)

Ronia knew it was sad for Noddle-Pete to be so old, but she did not understand why soldiers and fools would come and make trouble at the Wolf's Neck. In any case, she was sleepy and could not be bothered thinking about it. (AL1T)

Sometimes, as in (24), orka is accompanied by an NPI (heller 'either', in this case), but more often it is not. Negation may also be in a higher clause, as in (25), where orka occurs in the complement clause of förstod 'understood', and the main clause is negated by inte. We may gloss the first sentence with orka in (25) as 'she did not understand that they ORKA-past'. This particular sentence is left untranslated in ARP1T, where only the next (also negated) sentence receives a translation with couldn't be bothered.

(25) Och Henry instämde med kraft, och det blev en lovsång till Moralen och Ansvaret och Människokärleken som fastern hade kunnat klara sig utan. Hon förstod inte att de orkade. Själv orkade hon inte sitta här i den eländiga fåtöljen länge till, och när hon såg att klockan började närma sig två bad hon dem att skynda sig på. (ARP1) It would have been indecent not to set to work," he said. Henry forcefully concurred, and then it all grew into a hymn of praise to Morality and Responsibility and Love of 
Mankind which Auntie could have done without. She couldn't be bothered to sit there in that wretched armchair much longer, and when she saw it was almost two o'clock in the morning, she asked them to get a move on. (ARP1T)

In addition to sentence negation with inte ('not'), the material includes some other contexts that have been noted to trigger NPIs (e.g. by Lawler, 2005), such as negative adverbs like aldrig ('never') and negative pronouns functioning as Subjects or Objects, as in (26) and (27).

(26) Man tror sig veta att vi finns där men det är aldrig någon som orkar lägga märke till oss. (KOB1)

"They think they know we 're there, but nobody ever manages to notice us". (KOB1T)

(27) [...] och ingen hade under hela hösten orkat börja igen. (GT1)

And no one had been able to start again throughout the fall. (GT1)

Another common NPI trigger in the material is questions, as in (28).

(28) Där får han också syn på sitt bärande; just när han lagt henne ifrån sig och det far genom honom: "Hur länge skall jag orka samla barna?" (GT1)

There he glimpses his burden, just after he has put her down. It tears through him: "How long can I manage to keep the kids together?" (GT1T)

Finally, our data contain a small assortment of other NPI triggers, including a conditional clause, as in (29), a comparative clause, as in (30), and a relative clause modifying den ende ('the only [family member]'), as in (31).

(29) Han hade verkligen massor av kakel i denna källare bara han orkade ta sig ner i den och vågade trotsa kloakdofterna och öppna på dörren. (LG1)

He actually had hoards of tiles in the cellar if he could only manage to get himself down there and face the stench of the lavatory and open the door. (LG1T)

(30) Han höll kvar greppet så länge han orkade. (JG1)

He held the grip as long as he could. (JG1T)

(31) Karin hade varit den enda i släkten som kunnat och orkat ta sig an Nora. (MG1) Karin had been the only family member willing and able to take Nora on. (MG1T)

Conspicuous as this tendency may be, we nevertheless argue that it does not warrant an analysis of orka as an NPI. The obvious reason is that orka also occurs in unambiguously assertive contexts, as in (32).

(32) Men... det var knappast den slags hästar som frestade hans spel. Den lät sig spännas för barnens trilla redan första söndagen. Och orkade dra dem alla. (SCO1)

Then he showed me the pony, which he had also won. But... that kind of horse was hardly what tested his gambling. It allowed itself to be harnessed to the children's trap on the very first Sunday, and managed to pull them all. (SCO1T) 
Although there is only one such example in the SO texts and none in the ST texts, the assertive context in (32) alone seems to invalidate an analysis of orka as a strict NPI, at least on the standard assumption that NPIs are barred from assertive contexts. Further, we note that the use of orka in (32) is perfectly idiomatic, and has no additional interpretation.

Nevertheless, the overwhelming majority of orka in non-assertive contexts, all but one example, is real and needs to be accounted for. One potential approach is to regard orka as an NPI with a complex distribution across assertive and non-assertive contexts. English much is a notorious example of such complex distribution. For example, there is a sharp difference in acceptability between (33) and (34) (from Huddleston and Pullum, 2002: 826-827).

(33) a. *I enjoy sailing much.

b. I don't enjoy sailing much.

(34) This means much to the American tradition.

Huddleston \& Pullum argue that much is an NPI in (33) only, as indicated by its unacceptability in an assertive context, and that fairly fine-grained distinctions need to be made between different syntactic properties of a potential NPI. For orka, however, we see no comparable distinction between different uses of the verb that could account for the acceptability of example (32) above.

A second approach is to regard orka not as an NPI, but as part of a negative collocation associated with NPIs, an approach taken by van der Wouden (1994). While his approach is ultimately a formal semantic one, which is meant to account for the variability of use of NPIs within a particular language or across different languages, we adopt the basic idea. Specifically, the definition of collocations as co-occurrence tendencies between lexical items or, in an extended sense, between lexical items and syntactic/semantic contexts, allows the classification of orka as a polarity-sensitive verb with collocational tendencies to occur in non-assertive contexts.

A third interesting approach to explain the negative contexts of orka is suggested by Flint (1980: 134ff), who notes that Finnish verbs of possibility and sufficiency are very common in negative contexts. Her explanation, based on observations of the use of these verbs in interaction, is that they offer excuses, for example in response to requests or invitations. In other words, declining an invitation or refusing a request may be mitigated by making reference to a lack of sufficient time, energy, courage etc. For orka, then, which incorporates sufficiency with respect to mental or physical strength/energy, it is possible that its preponderance in non-assertive contexts stems from its frequent use as an excuse for noncompliance with invitations or requests. The exchange in (35) illustrates this use in our data.

(35) — Var är Eva-Liisa, jag vill att hon också...Gå och hämta henne.

- Jag orkar inte. (GT1)

"Where 's Eva-Liisa? I want her, too... Go get her".

"I can't". (GT1T)

Notice, incidentally, that, in this exchange, that the ability modal can serves much the same purpose, by referring to inability as an excuse for non-compliance with a request. As has been noted repeatedly in the literature on indirect speech acts, reference to ability is a common strategy both for making polite requests and for declining to comply with them (e.g. by Searle, 1975). What sufficiency verbs like orka contribute, then, is a more specific (in)ability 
than 'bare' ability modals like can. In our study of Swedish hinna 'have enough time' (Johansson and Nordrum, 2016), we do not explicitly address its use in negative contexts, but this verb, too, can certainly be used in a similar manner to express non-compliance, by referring to having insufficient time.

\subsection{Be bothered and volitional modality}

So far, we have argued that all correspondences of orka profile ability and involve sufficiency of strength/energy as an obstacle to ability. Further, we note that orka has collocational tendencies to figure in non-assertive contexts where insufficient strength/energy is highlighted as an obstacle to the Subject's ability. However, an interesting (albeit small) group of translations does not entirely fit this description. This group involves phrases like be bothered to and feel like (Table 2), which may be understood as expressing a lack of sufficient volition rather than ability. Examples are given in (36)-(38).

(36) Själv orkade hon inte sitta här i den eländiga fåtöljen länge till, och när hon såg att klockan började närma sig två bad hon dem att skynda sig på. (ARP1)

She couldn't be bothered to sit there in that wretched armchair much longer, and when she saw it was almost two o'clock in the morning, she asked them to get a move on. (ARP1T)

(37) Nej, hon vill inte. Hon orkar inte. (MR1)

No, she did not want to. She couldn't be bothered. (MR1T)

(38) Först på tisdagen orkade hon ta sig upp ur sängen.

She did not feel like getting up until Tuesday.

We take translations of this type to reflect a meaning that is derived from the sufficiency readings of orka. Some support for our assumption is that The Swedish Academy Dictionary (SAOB) explicitly claims that this meaning is secondary, and, moreover, that it is mainly found in informal registers today (although their earliest citation is from the 16th century).

\subsection{Orka!}

We end this section on a more speculative note, related to the volitional use of orka reflected in translations such as couldn't be bothered. In the speech of young Swedes, there is a relatively new development in the use of orka, common enough to be listed in internet dictionaries. Examples (39) and (40) are from www.slangopedia.se.

(39) Ska vi gå en promenad?

shall we go [for] a walk

- Men orka! Vi tankar en film istället.

"but ORKA we download a film instead".

(40) - Orka gå till skolan när betygen redan är satta!

"ORKA go to school when the grades are already set".

We interpret orka as volitional in these cases, i.e. what is conveyed is not a lack of sufficient energy to go for a walk or to school, but an unwillingness to do so. What is interesting about examples like these, however, is both that orka occurs in its base form (presumably as an imperative rather than an infinitive), and that the intended sense is negative, although there is 
no explicit negation. This second point relates to the observation above about the overwhelming tendency for orka to occur in non-assertive contexts. In informal terms, it appears that in (29) and (30), orka itself is capable of conveying this negative sense.

There are (at least) two ways of regarding the negative sense conveyed by orka in these examples. First, we may assume that we are simply dealing with irony or sarcasm, either of which can be understood in terms of some notion of 'saying the opposite of what you mean'. A similar explanation has been proposed within a variety of frameworks (e.g. Grice's cooperative principle). A corresponding example from English would be the use of Care! In the sense 'I don't care', illustrated by (41) (from The Urban Dictionary).

(41) Person one: oh wow! look at me i'm so great.

Person two: care.

A second approach to the negative use of orka is as a phenomenon referred to as hyponegation by Horn (2009), which can be found in expressions like I could care less, which is often castigated as a corrupted version of I couldn't care less. Some support for this approach is that just like I could care less, orka licenses NPIs, like längre ('any longer'), as illustrated in (31) and (32). ${ }^{6}$

(42) I could care less about ever going back to school. (= Horn's 28d)

(43) Orka vänta på Kalle längre! (our example)

The near synonym palla in Swedish is also used in this way, i.e. with predominantly volitional meaning and negative import but no overt negation. To what extent hyponegation and this kind of meaning are systematically related is an interesting topic for further study.

\section{Concluding discussion}

In this study, we aimed to shed light on the semantic profile of the Swedish verb orka as reflected in parallel corpus data. Our data support an analysis where most examples of orka reflect two meaning components: participant-internal ability and sufficiency of mental or physical strength. In line with Nadathur's (2016) proposal for the semantic profile of Finnish jaksaa, a verb similar to orka, we suggest that the sufficiency component of orka reflects an assumed obstacle, i.e. the presence of sufficient strength/energy, to the event reflected in orka's complement. We also assume that orka is a polarity-sensitive verb with collocational tendencies to occur in non-assertive contexts. This analysis is a specification of Teleman et al.'s (1999(4): 288) observation that orka refers to "whether the subject referent has sufficient strength or stamina to bring about the state of affairs in question, or "a more specified meaning than kunna 'can" [our translation]. In addition, our material includes some examples which reflect a second meaning of orka developed from the meaning presented above. In these cases, the sufficiency meaning concerns sufficient volition rather than physical or mental strength.

\footnotetext{
${ }^{6}$ An anonymous reviewer points out that a third possible approach to the imperative use of orka is the concept of semantic prosody (Sinclair 1991; Louw 1993). That is, it could be argued that orka has attained negative semantic prosody by way of its association with non-completion due to a lack of strength or willingness, and that this negative semantic prosody can be one contributing factor to imperative orka. This is an interesting approach for future studies.
} 
Our analysis of orka might contribute to a description of sufficiency as a semantic component relevant to modality. In light of our data, we tentatively suggest that rather than viewing the sufficiency component in orka as a specification of ability - in effect a subcategory of participant-internal possibility - the sufficiency meaning comprises a separate meaning layer that stretches across the modal meanings on modality's semantic map and also extends beyond the map.

Viewing sufficiency as a separate layer of a modality map makes sense since we see combinations of core modality and sufficiency all across the map. As we have shown here, orka combines ability (participant-internal possibility) and sufficiency. Further, we have previously shown that Swedish hinna 'have the time to' does the same, with sufficiency being participant-external (Johansson and Nordrum, 2016). Additionally, at least one other Swedish verb, slippa 'not have to' has a sufficiency component superimposed on participantexternal deontic modality. Example (44) illustrates slippa.

(44) Det fanns inget han hellre önskade än att hon dog. Då skulle han vara ensam kvar. Han skulle slippa att ringa henne, han skulle snart ha glömt hur hon ens såg ut. (HM1)

There was nothing he wanted more than for her to die. Then he'd be left alone. He wouldn't have to call her anymore, and soon he'd forget what she even looked like. (HMT1)

Our interpretation of slippa could be glossed as 'not undergoing sufficient external force to do sth'. Notice that the translation introduces an indication, anymore, that the external pressure to call her is exhausted at some point.

Another observation relevant to viewing sufficiency as a separate layer on Modality's map is the difference between so-called anankastic conditionals and similar constructions with only (see e.g. Huitink, 2005; von Fintel and Iatridou, 2007). This difference can be understood in terms of deontic modality with superimposed sufficiency. For example, the example of participant-external necessity offered in (6c) (section 1.1), and repeated here in (45), gets a sufficiency reading when supplemented by only.

(45) In order to get to the station, you have to take bus 66.

In order to get to the station, you only have to take bus 66 .

(i.e. it is sufficient that you take bus 66)

Our assumption that orka is a polarity-sensitive verb with collocational tendencies to occur in non-assertive contexts deserves some comments. We speculate that this collocational tendency is due to the status of orka as primarily an ability verb. Specifically, the added sufficiency component seems redundant in assertive contexts, where it is less relevant why someone was able to do something. Thus, we expect 'pure' ability modals where ability is asserted. Moreover, claiming that one has insufficient energy to do something by using negated orka serves the interactional purpose of politely declining invitations, refusing requests, etc., as pointed out by Flint (1980). This last observation raises a couple of interesting questions for further research. For example, it is possible that the use of orka in excuses has been instrumental in the development of a secondary volitional meaning, which, in addition, may carry the negative force on its own, as in the speech of young Swedish speakers. 


\section{References}

Aijmer, K. 2004. The semantic path from modality to aspect: Be able to in a cross-linguistic perspective. In Corpus Approaches to Grammaticalization in English, H. Lindqvist and C. Mair (eds), 57-79. Amsterdam/Philadelphia: John Benjamins.

Altenberg, B. and Aijmer, K. 2000. The English-Swedish Parallel Corpus: a resource for contrastive research and translation studies. In Corpus Linguistics and Linguistic Theory, C. Mair and M. Hundt (eds), 15-33. Amsterdam and Atlanta, GA: Rodopi.

Baglini, R. and Francez, I. 2016. The implications of managing. Journal of Semantics 33(3): 409-448.

Baker, M. 1992. In Other Words: a Course Book on Translation. London: Routledge.

Borin, L., Forsberg, M., and Roxendal J. 2012. Korp - the corpus infrastructure of Språkbanken. Proceedings of LREC, 2012. Istanbul: ELRA. 474-478.

Chesterman, A. 2007. What is a unique item? In Doubts and Directions in Translation Studies, Y. Gambier, M Shlesinger, and R. Stolze (eds), 3-13. Amsterdam: Benjamins,

Flint, A. 1980. Semantic Structure in the Finnish Lexicon: Verbs of Possibility and Sufficiency. Helsinki: Suomalaisen Kirjallisuuden Seura.

Fortuin, E. 2013. The construction of excess and sufficiency from a crosslinguistic perspective. Linguistic Typology 17:31-88.

Grice, H. P. 1975. Logic and conversation. In Syntax and Semantics, vol. 3, P. Cole, J.L. Morgan (eds), 41-58. New York: New York Academic Press.

Hacquard, V. 2005. Aspects of too and enough constructions. In Proceedings of Semantics and Linguistic Theory, E. Georgala and J. Howell (eds), 80-97. Ithacha, NY: Cornell University.

Horn, L. R. 2009. Hypernegation, hyponegation, and parole violations. In Annual Meeting of the Berkeley Linguistics Society, 403-423.

Huddleston, R. and Pullum, G. K. 2002. The Cambridge Grammar of the English Language. Cambridge: Cambridge University Press.

Huitink J. 2005. Analyzing anankastic conditionals and sufficiency modals. Proceedings of ConSOLE XIII. $135-156$

Johansson, M. and Nordrum, L. 2016. Swedish hinna viewed through its English correspondences have time or be able to? Nordic Journal of English Studies 15: 171-199.

Johansson, S. 2007. Seeing through Multilingual Corpora. Amsterdam/Philadelphia: John Benjamins.

Lagervall, M. 2014. Modala Hjälpverb i Språkhistorisk Belysning. Göteborgsstudier i Nordisk Språkvetenskap 23. Göteborgs universitet: Institutionen för Svenska Språket.

Lawler, J. 2005. Negation and NPIs. http://www-personal.umich.edu/ jlawler/NPIs.pdf [last accessed 15 November 2017].

Louw, B. 1993. Irony in the text or insincerity in the writer? The diagnostic potential of semantic prosodies. In Text and Technology: In Honour of John Sinclair. M. Baker, G. Francis and E. Tognini-Bonelli (eds), 157-175. Amsterdam: John Benjamins.

Meier, C. 2003. The meaning of too, enough and so ... that. Natural Language Semantics 11: 69-107.

Nadathur, P. 2016. Causal necessity and sufficiency in implicativity. In Proceedings of SALT 26, M.Moroney, C-R Little, J. Collard and D. Burgdorf (eds), 1002-1021.

Nida, E.A. and Taber, C.R. 1982. The Theory and Practice of Translation. Leiden: E.J. Brill.

Petti, V. (ed). 2000. Norstedts Stora Svensk-Engelska Ordbok. 3rd ed. Stockholm: Norstedts ordbok.

Searle, J. R. 1975. Indirect speech acts. In Syntax and Semantics, vol. 3: Speech Acts, P. Cole and J. L. Morgan (eds), 59-82. New York: Academic Press

Sinclair, J. 1991. Corpus, Concordance, and Collocation. Oxford: Oxford University Press.

Teleman, U., Hellberg, S., and Andersson, E. 1999. Svenska Akademiens Grammatik, vol. 1-4. Stockholm: Svenska Akademien.

van der Auwera, J. and Plungian, V. A. 1998. Modality's semantic map. Linguistic Typology 1998(2): $79-124$.

van der Auwera, J., Kehayov, P., and Vittrant, A. 2009. Acquisitive modals. In Cross-linguistic Semantics of Tense, Aspect and Modality, L. H. Hogeweg, d. Hoop and A. L. Malchukov (eds), 271-302. Amsterdam: John Benjamins. 
van der Wouden, T. 1994. Negative Contexts. Groningen Dissertations in Linguistics. Groningen: University of Groningen.

von Fintel, K. 2006. Modality and language. In Encyclopedia of Philosophy - Second Edition vol. 10, D. M. Borchert (ed.), 20-27. Detroit: MacMillan Reference USA.

von Fintel, K. and S. Iatridou. 2007. Anatomy of a modal construction. Linguistic Inquiry 38: 445-83.

\section{Corpora and online dictionaries:}

“care, v." Urban Dictionary September 2003, https://www.urbandictionary.com/ define.php?term=Care [last accessed 15 November 2017].

“orka" Slangopedia August 2008, http://www.slangopedia.se/ordlista/?ord=orka [last accessed 15 November 2017].

"orka" Svenska Akademiens Ordbok (SAOB) 1950 https://svenska.se/saob/?id=010550260. Q $\mathrm{Bq} \& \mathrm{pz}=7$ [last accessed 15 November 2017].

The Amsterdam Slavic Parallel Aligned Corpus (ASPAC) Available at https://spraakbanken.gu.se/korp [last accessed 15 nov 2017].

The English-Swedish Parallel Corpus (ESPC) Available at http://www.tekstlab.uio.no/cgibin/omc/PerlTCE.cgi [last accessed 15 November 2017].

The European Parliament Proceedings Parallel Corpus (Europarl) Available at https://spraakbanken.gu.se/korp [last accessed 15 November 2017].

Authors' address

Mats Johansson / Lene Nordrum

Centre for languages and literature

Lund University

Box 201

22100 Lund

Sweden

mats.johansson@englund.lu.se / lene.nordrum@englund.lu.se 